\title{
PERUBAHAN OTOT RANGKA PADA OLAHRAGA
}

\author{
Sonny J. R. Kalangi \\ Bagian Anatomi-Histologi Fakultas Kedokteran Universitas Sam Ratulangi Manado \\ Email: sonnykalangi@yahoo.com
}

\begin{abstract}
Sports can enhance physical fitness and defence mechanism of the body. In the cellular and tissue levels, sports can improve the shape, function, defence, and strength of skeleton muscles. Although muscle cells can not undergo mytosis anymore, the injured muscle fibers can still be replaced by new fibers. During this regeneration process, the growth of new fibers compete with the growth of connective tissue. If there is less oxygen supply regeneration of muscle tissues will be hindered meanwhile the connective tissue can grow unimpededly. The changes of skeletal muscles are influenced by the endurance of physical training. As long as the physical training does not exceed the adaptation limit of the body, sport injury does not occur. Due to the regular physical training, all systems of the body will be improved, as well as the strength and skeletal muscle sizes. Therefore, the muscles can protect the joints against sudden external trauma.
\end{abstract}

Keywords: sport, regeneration, muscle hypertrophy, sport injury

\begin{abstract}
Abstrak: Olahraga, terutama bila dilakukan secara teratur, dapat meningkatkan kesegaran jasmani serta daya tahan. Pada tingkat sel dan jaringan olahraga dapat memperbaiki bentuk, fungsi, ketahanan, dan kekuatan otot rangka. Otot rangka tergolong jaringan yang purnakembang artinya sel-selnya tidak dapat membelah lagi untuk memperbanyak diri. Sekalipun serat ototnya tidak dapat membelah lagi otot yang rusak dapat diganti dengan serat baru sehingga pulih-asal seperti sediakala. Dalam proses regenerasi, pertumbuhan serat otot baru bersaing dengan pertumbuhan jaringan ikat. Jika pasokan oksigen terhambat, regenerasi jaringan otot akan terganggu sedangkan jaringan ikat akan lebih leluasa tumbuh. Perubahan yang terjadi pada otot rangka sesuai dengan beban latihan. Sepanjang latihan tidak melampaui batas kemampuan penyesuaian tubuh, umumnya tidak akan terjadi cedera otot. Dengan latihan yang teratur sistem dalam tubuh akan menjadi makin baik mutu kerja dan kekuatannya, dan ukuran serat otot bertambah besar (hipertrofi). Ketahanan dan kekuatan otot yang baik akan dapat melindungi sendi terhadap cedera yang disebabkan oleh beban tambahan yang mendadak dari luar.
\end{abstract}

Kata kunci: olahraga, regenerasi, hipertrofi otot, cedera olahraga

Apakah manfaat olahraga? Bagi siapapun, setiap jenis olahraga mempunyai arti khusus. Olahraga, terutama bila dilakukan secara teratur telah terbukti meningkatkan kesegaran jasmani serta daya tahan pelakunya. Otot jantung menjadi kuat dan kemampuan paru serta kapasitas pernapasan menjadi lebih baik, peredaran darah ke alat- alat tubuh, otot dan kulit bertambah, dengan demikian memperbaiki penyediaan bahan makanan yang diperlukan organ tersebut serta meningkatkan pembuangan sisa metabolisme yang mungkin membahayakan.

Latihan fisik yang terarah dapat memperbaiki bentuk, fungsi, ketahanan, dan 
kekuatan otot rangka. Perbaikan itu didasari oleh perubahan di tingkat sel dan jaringan. Demikian pula jika terjadi kerusakan akibat latihan yang berlebihan atau kecelakaan, perbaikan atas kerusakan itu juga bergantung kepada perbaikan di tingkat yang sama. Otot yang tampak normal dari luar, belum tentu berfungsi normal jika telah terjadi kerusakan permanen di dalamnya. Oleh karena itu berbagai perubahan mendasar pada otot rangka akibat latihan perlu dipahami agar latihan dapat dilakukan dan dimanfaatkan sebaik mungkin.

Uraian di atas menggambarkan bagaimana latihan jasmani terutama bila dilakukan secara teratur membawa kesegaran jasmani secara menyeluruh bagi pelakunya. Penampilan fisik yang baik dengan rona yang sehat berseri jelas merupakan keuntungan, selain itu otot-otot tubuh lebih mampu dan tahan melakukan pekerjaan berat tanpa cepat merasa lelah, hal ini merupakan suatu peningkatan daya tahan (endurance).

\section{JARINGAN OTOT}

Tubuh kita tersusun oleh empat jaringan dasar, salah satunya ialah jaringan otot. Jaringan otot terdiri dari tiga jenis, yaitu: otot rangka (skeletal muscle), otot jantung (cardiac muscle), dan otot polos (smooth muscle). Pada setiap jaringan otot terdapat sejumlah besar serat atau sel otot yang dibungkus dalam jalinan serabut jaringan ikat sebagai penyokong yang kata dengan pembuluh darah dan serat saraf. Semua unsur jaringan ikat itu diperlukan agar jaringan otot dapat menjalankan tugasnya dengan baik, yaitu menghasilkan gerak, baik yang disadari maupun yang tidak disadari. ${ }^{1-7}$

Otot rangka hampir semuanya melekat pada tulang dan berfungsi menggerakkan tulang itu pada sendinya. Otot jantung membentuk jantung dan otot polos membentuk dinding setiap saluran yang ada dalam tubuh kita misalnya, pembuluh darah, saluran cerna, saluran kemih, dan lainnya. ${ }^{1-7}$
Gerak otot rangka hampir seluruhnya di bawah pengaruh kemauan kita, karena itu otot rangka disebut juga otot sadar. Sebaliknya otot jantung dan otot polos, keduanya menghasilkan gerak tanpa disadari, di luar kemauan kita, dan disebut tak sadar. Gerak otot jantung dan otot polos dapat berubah iramanya secara otomatis. ${ }^{1-7}$

Otot dapat dipandang sebagai suatu motor yang bekerja dengan jalan mengubah energi kimia menjadi tenaga mekanik kontraksi dan pergerakan. Sifat istimewa setiap serat otot untuk berkontraksi terletak pada interaksi protein khusus, aktin, miosin dan troponin, dengan retikulum sarkoplasmik dan ion kalsium memegang peranan menggandengkan rangsangan dengan kontraksi (excitation-contraction coupling). ${ }^{1-7}$

\section{Otot rangka}

Unit organisasi otot rangka ialah serat otot dengan sel-sel yang multinuklear berbentuk silindrik panjang. Serat otot ini lebih panjang daripada serat otot polos. Panjangnya berkisar antara $10-30 \mathrm{~cm}$ dan diameter 0,1-0,5 mm. Serat-serat tersusun paralel berkumpul dalam berkas-berkas serat atau fasikulus yang cukup besar untuk dapat dilihat dengan mata telanjang. ${ }^{1-7}$

Jaringan ikat padat yang membungkus otot disebut epimisium. Sekat tipis yang masuk ke dalam dari epimisium untuk meliputi tiap fasikulus ialah perimisium dan jaringan ikat yang meliputi setiap serat otot disebut endomisium. Pembuluh darah yang memasok darah pada otot rangka bercabangcabang pada epimisium dan mengadakan penetrasi melalui sekat perimisium untuk membentuk, dalam endomisium, banyak jaringan kapiler sekitar serat-serat otot. ${ }^{1-7}$

Serat otot dibungkus oleh suatu membran plasma yang disebut sarkolema dan sitoplasmanya disebut sarkoplasma. Di dalam sarkoplasma terdapat perangkat kontraktil sel yaitu miofibril yang tersusun dalam berkas-berkas. Di dalam setiap 
miofibril terdapat protein kontraktil yang disebut miofilamen. Miofilamen ini susunannya teratur sehingga menghasilkan gambaran lurik. Pada setiap serat terdapat banyak inti sel yang terletak berderet-deret di tepian serat di bawah sarkolema. Di samping itu terdapat perangkat metabolisme sel lainnya yang secara umum disebut organel sitoplasma. Di antara organel itu yang menonjol jumlahnya ialah mitokondria. ${ }^{1-7}$

Jenis serat otot rangka digolongkan atas serat otot merah (red fibers), serat otot putih (white fibers), dan serat otot menengah (intermediate fibers). Pada manusia serat otot merah mungkin terdapat pada hampir semua otot tubuh, namun terutama pada otot yang bertugas untuk menyanggah berat badan di waktu berdiri, sedangkan serat otot putih terdapat pada semua otot tubuh terutama otot untuk gerak cepat. ${ }^{4,7,8}$

Jenis serat otot yang diidentifikasi secara genetik terdapat lima jenis, yaitu: ${ }^{4,8}$

\section{Tipe I}

Disebut juga serat otot berkontraksi lambat (slow-twitch fiber). Jenis otot ini paling lambat untuk berkontraksi, tetapi lebih tahan terhadap kelelahan otot. Terdapat banyak mitokondria dan mioglobin dan sedikit glikogen dan enzim glikolisis.

2. Tipe IIA

Serat oksidatif kontraksi cepat (serat merah). Jenis ini lebih banyak mitokondria dan mioglobin daripada tipe IIB tetapi lebih sedikit dari tipe I dan berkontraksi lebih cepat dari tipe I.

3. Tipe IIB

Serat glikolisis kontraksi cepat (serat putih). Tipe ini juga berkontraksi cepat tetapi lebih mudah mengalami kelelahan otot.

4. Tipe IIC

Serat menengah mengandung kedua jenis serat kontraksi cepat (serat merah dan putih).

5. Tipe IIM

Serat sangat cepat (superfast fiber) dengan suatu miosin unik yang tidak terlihat pada serat otot jenis lain. Tipe serat otot ini ditemukan pada otot-otot rahang.

Bentuk otot rangka bervariasi, yaitu bentuk fusiform (berbentuk gelendong) dan bentuk pennate (berbentuk seperti bulu). Bentuk otot pennate terdiri dari multipennate, bipennate, dan unipennate. ${ }^{8}$

\section{Regenerasi otot rangka}

Otot rangka tergolong jaringan yang purna-kembang artinya sudah tidak berubah lagi, sel-selnya tidak membelah lagi untuk memperbanyak diri. Contoh lain dari jaringan tubuh kita yang juga purnakembang ialah jaringan otak. Setelah lahir, jaringan otak tidak bertambah lagi jumlah selnya selain menyesuaikan dengan bertambah besarnya badan kita. Demikian pula jaringan otot rangka. Namun, ternyata jaringan otot rangka memiliki keistimewaan. Sekalipun sel-selnya sudah tidak dapat membelah lagi untuk memperbanyak diri, melalui cara yang unik serat otot yang rusak dapat diganti dengan serat baru sehingga pulih-asal seperti sediakala. Artinya jaringan otot dapat 'beregenerasi' sampai batas tertentu. ${ }^{1,4-6,8}$

Sebenarnya, pada setiap serat otot rangka, di luar sarkolema terdapat 'selongsong' khusus yang disebut membran basal. Pada beberapa tempat di sepanjang serat, di bawah membran basal tadi tetapi di luar sarkolema terdapat sel satelit yang merupakan sel 'cadangan' yang dapat berkembang menjadi sel otot jika terjadi kerusakan pada serat tersebut. Itulah yang memungkinkan sel otot rangka mempunyai kemampuan beregenerasi. Bila kerusakannya terlalu luas, sebagian jaringan otot yang rusak akan diganti dengan jaringan parut yang kurang liat dan agak kaku sehingga lebih mudah cedera. Agar regenerasinya berjalan sempurna, diperlukan berbagai prasyarat yang harus diperhatikan. ${ }^{1}$ 
Regenerasi serat otot rangka makan waktu paling tidak 21 hari untuk dapat pulihasal. Pada hari ketiga, jumlah serat yang rusak mungkin masih bertambah karena terhambatnya pasokan darah ke tempat yang cedera akibat pembengkakan setempat. Karena itu, agar dapat terjadi regenerasi yang sempurna diperlukan pengistirahatan yang diselingi mobilisasi ringan, agar aliran darah lancar dan pembentukan serat baru terarah sempurna. Dengan demikian setelah sembuh, otot dapat berfungsi normal kembali. ${ }^{1}$

Dalam regenerasi, pertumbuhan serat baru bersaing dengan pertumbuhan jaringan ikat. Jika pasokan oksigen terhambat, regenerasi akan terganggu dan jaringan ikat akan lebih leluasa tumbuh. Bila otot kurang diistirahatkan, serat yang rusak akan bertambah terus sebab kebutuhan oksigen semakin meningkat sedangkan aliran darah akan makin terhambat karena pembengkakan terus membesar akibat perdarahan baru dan radang. Akibatnya, pertumbuhan serat otot baru pun terhambat dan jaringan ikat lebih leluasa tumbuh mengisi ruangan yang semula ditempati oleh serat otot. Akhirnya, terbentuklah jaringan parut yang luas dibekas cedera otot itu. Bila hal ini terjadi, otot tersebut akan lebih mudah cedera lagi bila digunakan kelak setelah sembuh dan kekuatannya pun berkurang. ${ }^{1,9}$

\section{PERUBAHAN OTOT RANGKA AKIBAT OLAHRAGA}

Olahraga sebenarnya bukan hanya memengaruhi otot, tetapi juga memengaruhi keseluruhan sistem pergerakan, yaitu: tulang, sendi, ikat sendi, otot, tendo, saraf, dan pembuluh darahnya secara berimbang. Perubahan yang terjadi sesuai dengan beban latihan. Sepanjang latihan itu tidak melampaui batas kemampuan penyesuaian tubuh, pada umumnya tidak akan terjadi cedera akibat latihan. Dengan latihan yang teratur semua sistem akan menjadi makin baik mutu kerjanya dan kekuatannya. ${ }^{9-13}$

Melalui latihan, ukuran serat otot bertambah besar (hipertrofi otot), dengan demikian diameter otot menjadi besar. Jadi ketahanan dan kekuatan otot bertambah baik, sehingga otot akan dapat melindungi sendi terhadap cedera yang disebabkan oleh beban tambahan yang mendadak dari luar. ${ }^{9-13}$

Pada dasarnya perubahan yang terjadi pada latihan adalah bertambahnya jumlah pembuluh darah, diameter serat otot, dan organel intrasel. Bertambahnya kekuatan otot yang diperoleh melalui latihan tidak dapat diperoleh begitu saja. Memerlukan waktu latihan rutin selama dua bulan barulah akan didapat peningkatan yang bermakna. Peningkatan kekuatan ini harus dipelihara terus sebab peningkatan yang telah dicapai dalam waktu dua bulan itu akan hilang sama sekali jika tidak berlatih selama lima bulan berikutnya.Tubuh cepat menyesuaikan diri dengan kebutuhan jasmani. Bila kebutuhan berkurang maka massa otot akan berkurang (atrofi otot), dan volume darah yang mengalir ke otot juga berkurang. Akibatnya efisiensi pengangkutan oksigen dari paru ke jaringan juga menurun dan akhirnya pasokan energi ke ototpun ikut menurun. ${ }^{9-13}$

Jenis latihan otot bermacam-macam. Secara garis besar dapat dikelompokkan menjadi dua kegiatan. Pertama, latihan statis, artinya otot berkontraksi tetapi tidak menghasilkan gerakan. Kedua, latihan dinamis, artinya terjadi kontraksi otot yang menghasilkan gerakan pada sendi. Dalam latihan dinamis terdapat dua jenis gerakan, yaitu gerakan konsentrik, anggota badan mendekati tubuh, dan gerakan eksentrik anggota badan menjauhi tubuh. Pada kedua gerakan dinamis ini terjadi pemanjangan dan pemendekan sekaligus. ${ }^{9-}$

Kedua jenis latihan di atas mempunyai pengaruh yang berbeda pada sifat otot, sekalipun dasar perubahannya sama. Latihan statis biasanya digunakan pada latihan awal untuk rehabilitasi pascacedera, sedangkan latihan dinamis dilakukan setelah pemulihan 
dianggap sempurna. Latihan dinamis dapat memperbaiki kekuatan otot atau memelihara tingkat kekuatannya pada taraf tertentu tanpa mengurangi kecepatan geraknya, sedangkan latihan statis dapat mengurangi kecepatan gerak, artinya gerak otot yang bersangkutan menjadi lamban. ${ }^{9-13}$

Pada saat istirahat volume darah total yang mengalir ke otot hanya $15-20 \%$, setelah 10-20 menit pemanasan, jumlah darah yang mengalir ke otot meningkat sampai $70-75 \%$. Di sini terlihat betapa besarnya otot mengambil pasokan darah agar dapat berfungsi normal. Otot akan memperlihatkan kemampuan maksimal jika seluruh pembuluh darahnya berfungsi. Dengan begitu artinya pemanasan sangat membantu mempertinggi kemampuan otot dan sekaligus mencegah kemungkinan cedera. $8,9,11-13$

\section{CEDERA OTOT}

Cedera otot dapat terjadi akibat kecelakaan olahraga ataupun latihan berlebihan. Latihan yang tidak mengikuti tatacara dapatberakibat cedera. Cedera otot dapat beragam bentuknya dan beratringannya. Penyebabnya yang umum ialah tarikan berlebijhan atau gerakan kuat mendadak, yang dapat merobek fascia atau bahkan otot atau tendonya. Selain itu cedera dapat pula timbul akibat tekanan kuat misalnya pada benturan. ${ }^{14,15}$

Dalam hal cedera ini, yang penting ialah mengenal secara dini cedera yang memerlukan penanganan medis. Jika cedera itu ringan, nyeri akan hilang segera atau berangsur dalam beberapa hari. Memaksa latihan pada otot yang cedera dapat dipastikan akan menurunkan kekuatannya dan mengundang cedera ulang di masa mendatang setelah sembuh. Agar lebih mudah memahami, lihatlah bagan di bawah ini yang pada dasarnya menekankan adanya lingkaran setan pada otot cedera yang tidak diistirahatkan, akibatnya cedera otot semakin parah. $^{14,15}$

Cedera otot yang paling ringan adalah nyeri otot pasca latih. Nyeri semacam ini dapat terjadi pada setiap orang pasca latihan. Kadang dapat timbul pembengkakan otot dan muncul beberapa jam setelah latihan berat. Nyeri dapat berasal dari satu atau sekelompok otot. Rasa nyeri itu timbul pada saat bergerak ataupun diam; dan otot yang tersebut akan terasa lemah. Cedera seperti ini dapat terjadi pada 'start' yang terlalu kuat dan mendadak, pada latihan yang sekaligus memanjang dan memendekkan otot, dan pada orang yang sudah lama tidak berlatih. Selain itu, juga dapat terjadi pada latihan yang lain dari biasanya. ${ }^{14,15}$

Sebenarnya cedera itu terjadi pada unit kontraksi yang paling kecil yaitu sistem miofilamen, miofibril, dan dapat pula disertai pecahnya pembuluh kapiler darah. Akibatnya terjadi reaksi radang dan pembengkakkan yang menjadikan aliran darah terhambat dan timbulnya rasa nyeri dan kaku. Namun demikian keadaan ini tidak berbahaya dan akan berangsur hilang dalam beberapa hari. ${ }^{14,15}$

Untuk menghindari kejadian seperti itu perlu dilakukan langkah-langkah berikut: ${ }^{14,15}$

- Sesuaikan program latihan dengan hasil yang hendak dicapai dan gunakanlah peralatan yang sesuai.

- Jika nyeri ringan, latihan dapat diteruskan tetapi sedikit diubah. Intensitas latihan dinaikkan bertahap, terutama pada tahap awal.

- Gerakan yang kalem tidak akan menambah nyeri. Lingkungan yang hangat dapat membantu penyembuhan.

Cedera dapat pula berat misalnya putusnya tendo, robekan fascia, robekan otot, dan hematom. Cedera seperti ini biasanya akan semakin sakit jika digunakan untuk bergerak, dan sakitnya tidak mereda dalam waktu 24-48 jam.

Terdapat beberapa keadaan yang memudahkan terjadinya cedera. Hal-hal 
tersebut di bawah ini perlu diwaspadai dan jika ditemukan langkah khusus harus diambil agar cedera dapat dihindari. Keadaan tersebut ialah: ${ }^{14,15}$

- Kurang persiapan, kurang pemanasan.

- Otot yang melemah akibat cedera yang terjadi sebelumnya, dan rehabilitasi yang salah.

- Bekas cedera dengan jaringan parut yang luas.

- Otot yang kelelahan dan tarikan yang berlebihan.

- Otot yang terlalu pendek lebih mudah cedera pada olahraga yang mengandalkan kelenturan.

- Otot yang terlalu lama kedinginan, kurang kontraktil.

\section{SIMPULAN}

Serat otot rangka terdapat tiga jenis, yaitu: serat otot merah, serat otot putih, dan serat otot menengah. Secara genetik jenis serat otot dibagi dalam lima golongan, yaitu: tipe I, tipe IIA, tipe IIB, tipe IIC, dan tipe IIM.

Jaringan otot rangka mempunyai susunan mikroskopik yang unik. Sel otot rangka akan berubah struktur dan organisasinya sesuai dengan kebutuhan sehingga kemampuan otot rangka dapat ditingkatkan. Dengan latihan serat otot akan membesar (hipertrofi), jumlah organel sel meningkat, dan jumlah pembuluh darahpun bertambah. Sejalan dengan itu kandungan energi dan tingkat metabolismenya pun naik, sehingga kekuatan dan ketahanannya makin tinggi.

Otot rangka mampu beregenerasi tetapi cedera otot tetap harus ditangani dengan baik. Latihan yang baik dan benar akan dapat menghindari cedera.

Telah dibawakan pada seminar "Connective tissue and musculoskeletal disorders" yang diselenggarakan oleh Perhimpunan Ahli Anatomi Indonesia
Komisariat Manado tanggal 3 Oktober 2014 di Manado.

\section{DAFTAR PUSTAKA}

1. Cormack DH. Muscle Tissue. Ham's Histology (Ninth Edition). Sydney: J.B. Lippincott Company, 1987; p. 389-422.

2. Fawcett DW. Muscle. A Textbook of Histology (Twelfth Edition). London: Chapman \& Hall, 1994; p. 266-92.

3. Wynsberghe DV, Noback CR, Carola R. Human Anatomy and Physiology (Third Edition). Toronto: McGraw-Hill Inc, 1995.

4. Mescher AL. Junqueira's Basic Histology Text \& Atlas (Twelfth Edition). New York: Mc GrawHill, 2010.

5. Gartner P, Hiatt JL. Color Textbook of Histology (Third Edition). Philadelphia: Saunders Elsevier, 2007.

6. Ross MH, Wojciech P. Histology A Text and Atlas with Correlated Cell and Molecular Biology (Sixth Edition). Philadelphia: Lippincott Williams \& Wilkins Wolters Kluwer, 2011.

7. Tortora GJ, Derrickson B. Principles of Anatomy \& Physiology (Thirteenth Edition). Danvers: John Wiley \& Sons Inc, 2012.

8. Buckley PD, Grana WA, Pascale MS. The biomechanical and physiological basis of rehabilitation. In: Grana WA, Kalenak A, editors. Clinical Sports Medicine. Tokyo: WB Saunders Company, 1991; p. 23942.

9. Wonodirekso S. Pengaruh latihan pada jaringan otot rangka. Simposium Perubahan Struktur, Faal, dan Biokimia Jaringan Otot Rangka karena Latihan. KONI DKI JAYA. Jakarta, 10 Januari 1992.

10. Davis RJ, Bull CR, Roscoe JV, Roscoe DA. Physical Education and the Study of Sports (Second Edition). Toronto Wiesbaden: Mosby, 1994 (1995); p. 2447.

11. Hazeldine R. Fitness for Sport. Wiltshire: The Crowood Press, 1985 (1994); p. 667.

12. Newsholme E, Leech T, Duester G. Keep 
178 Jurnal Biomedik (JBM), Volume 6, Nomor 3, November 2014, hlm. 172-178

on running: The Science of Training and Performance. Muscles and Movement. Singapore: John Wiley \& Sons, 1994.

13. Marini M, Veicsteinas A. The exercised skeletal muscle: a review. European Journal Translational Myology. 2010;20(3):105-20.
14. Peterson L, Renstrom P. Sports Injuries; Their Prevention and Treatment. London: Martin Dinitz, 1988.

15. Close GL, Kayani A, Vasilaki A, McArdle A. Skeletal muscle damage with exercise and aging. Sports Med. 2005;35(5):41327. 